\title{
STRATEGI PEMERINTAH DAERAH DALAM MENINGKATKAN KINERJA PELAYANAN PUBLIK DI LINGKUNGAN SEKRETARIAT DAERAH KABUPATEN BOLAANG MONGONDOW UTARA
}

\author{
Zuchri Abdussamad dan Ritmon Amala \\ Fakultas Ekonomi Universitas Negeri Gorontalo \\ Email:zuchriabdussamad@yahoo.com
}

\begin{abstract}
This research aims to know and describe the Strategy Of Local Government In Order To Increasing Perform Of Public Service In Environment Secretariat Local Regency of North Bolaang Mongondow and also to know and describe what factors that constraint the strategy of local government to increase perform of public service in that region by using phenomenologist approach in qualitative research, while in order to collect the data, this research use observation, interview, and documentation. The result of research show that the Strategy of Local Government Specifically In Environment Secretariat Local Regency of North Bolaang Mongondow consist of three points that become the strategy of local government that include in plannning strategy, they are (1). Increasing perform of apparatus (2) Develop SOP and SPM (3). Increasing medium and supporting medium. Those all show that still so far from expectation, this case prove by human resources that really minimum both quality and quantity, the implementation of SOP and SPM not balance in parts of organization, and also about the medium and supporting medium of public service are not equal, particularly in IT such as telecom and fax. So that is way, the government should increase training of technological guidance in order to develop competence of apparatus, SOP and SPM and also apply it in perform of public service. Besides that, factor that constraint the strategy of local government to increase perform of public service in that region show that human resources, mutation, and also budget is very influence, this case is because human resources is still minimum, mutation that not appropriate with skill and should adjust with new environment, while the minimum of budget makes it cannot accommodate something which is needed in public service.
\end{abstract}

Keywords: Strategy, Perform, Service, Public.

\begin{abstract}
Abstrak: Penelitian ini bertujuan untuk mengetahui dan mendiskripsikan Strategi Pemerintah Daerah dalam Meningkatkan Kinerja Pelayanan Publik dilingkungan Sekretariat Daerah Kabupaten Bolaang Mongondow Utara dan juga untuk mengetahui serta mendeskripsikan faktor-faktor apa yang menghambat strategi pemerintah daerah dalam meningkatkan kinerja pelayanan publik dilingkungan Sekretariat Daerah Kabupaten Bolaang Mongondow Utara, dengan menggunakan pendekatan fenomenologis, penelitian kualitatif, teknik pengumpulan data dilakukan dengan cara observasi, wawancara, dan dokumentasi. Hasil penelitian menunjukan bahwa Strategi Pemerintah Daerah khususnya dilingkungan Sekretariat Daerah Kabupaten Bolaang Mongondow Utara yakni dengan mengacu pada tiga hal yang menjadi strategi pemerintah daerah yang tertuang dalam renstra yaitu (1). Meningkatkan kompetensi aparatur (2). Mengembangkan SOP dan SPM, (3). Meningkantkan sarana prasarana penunjang. Menunjukan masih sangat jauh dari harapan, hal ini dibuktikan dengan Sumber Daya Manusia yang sangat minim baik dari
\end{abstract}


kualitas maupun kuantitasnya, penerapan SOP dan SPM yang tidak merata pada bagianbagian organisasi, serta tidak memadainya sarana prasarana penunjang pelayanan publik, utamanya pada IT seperti telekomunikasi maupun fax. Sehingga Pemerintah Daerah perlu meningkatkan pelatihan bimtek untuk pengembangan kompetensi aparatur, SOP dan SPM serta mengimplementasikan dalam kinerja pelayanan publik. Selain itu juga yang menjadi faktor yang menghambat strategi Pemerintah Daerah dalam meningkatkan kinerja pelayanan publik dilingkungan Sekretariat Daerah menunjukan bahwa Sumber Daya Manusia, Mutasi, maupun Anggaran sangatlah berpengaruh, hal ini dikarenakan Sumber Daya Manusia yang rendah, terjadi mutasi yang tidak sesuai dengan keahlian dan harus menyesuaikan lagi dengan lingkungan kerja yang baru, serta anggaran yang sangat minim sehingga tidak dapat mengakomodir segala sesuatu yang dibutuhkan dalam pelayanan publik.

Kata Kunci : Strategi, Kinerja, Pelayanan, Publik.

\section{PENDAHULUAN}

Sistim pemerintahan Indonesia terdapat pembagian wilayah atas Daerah-daerah Provinsi, Kabupaten, Kota. Tiap Provinsi, Kabupaten dan Kota itu mempunyai pemerintahan daerah yang diatur dengan Undang-undang. Hubungan wewenang antara Pemerintah Pusat dan Pemerintah Daerah Provinsi, Kabupaten/Kota atau antara Pemerintah Provinsi dan Kabupaten/Kota, diatur dengan Undang-undang dengan memperhatikan kekhususan dan keragaman daerah. Selain itu negara mengakui dan menghormati satuan-satuan Pemerintahan Daerah yang bersifat istimewa dan menghormati kesatuan-kesatuan masyarakat hukum adat beserta hak-hak tradisionalnya sepanjang masih hidup dan sesuai dengan perkembangan masyarakat dan prinsip Negara Kesatuan Republik Indonesia.

Penyelenggaraan Pemerintahan Indonesia, yakni menganut asas desentralisasi, dekonsentrasi, dan tugas pembantuan. Prinsip penyelanggaraan desentralisasi adalah otonomi seluas-luasnya dalam arti daerah-daerah diberikan kewenangan mengatur dan mengurus semua urusan pemerintahan diluar yang menjadi urusan Ppemerintah. Daerah memiliki kewenangan membuat kebijakan daerah untuk memberikan pelayanan, peningkatan peran serta, prakarsa dan pemberdayaan masyarakat yang bertujuan pada peningkatan kesejahteraan rakyat.

Undang-undang Nomor 32 Tahun 2004 tentang Pemerintahan Daerah, secara eksplisit memberikan otonomi yang luas kepada pemerintah daerah untuk mengurus dan mengelola berbagai kepentingan dan kesejahteraan masyarakat. Pemerintah daerah harus mengoptimalkan pembangunan daerah yang berorientasi kepada kepentingan masyarakat. Melalui Undang-undang Nomor 32 Tahun 2004, pemerintah daerah dan masyarakat di daerah lebih diberdayakan sekaligus diberi tanggung jawab yang lebih besar untuk mempercepat laju pembangunan daerah. Sejalan dengan hal tersebut maka implementasi kebijakan otonomi daerah telah mendorong terjadinya perubahan, baik secara struktural, fungsional, maupun secara kultural dalam tatanan penyelenggaraan pemerintahan daerah, misalnya pemberlakuan e-Goverment. Menurut (Susartono, 2006: 2), Pemerintah mulai menyadari perlunya pengembangan e-Goverment di seluruh jajaran pemerintahan, maka pada Tahun 2003 dikeluarkan Inpres No. 3 Tahun 2003 mengenai pengembangan eGoverment di Indonesia. 
Mewujudkan pemerintahan yang baik menjadi suatu hal yang tidak dapat ditawar lagi keberadaannya dan mutlak terpenuhi. Prinsip-prinsip pemerintahan yang baik meliputi antara lain: akuntabilitas yang diartikan sebagai kewajiban untuk mempertanggungjawabkan kinerjanya. Keterbukaan dan transparansi (openness and transparency) dalam arti masyarakat tidak hanya dapat mengakses suatu kebijakan tetapi juga ikut berperan dalam proses perumusannya. Ketaatan pada hukum dalam artian seluruh kegiatan didasarkan pada aturan hukum yang berlaku dan aturan hukum tersebut dilaksanakan secara adil dan konsisten. Partisipasi masyarakat dalam berbagai kegiatan pemerintahan umum dan pembangunan.

Penerapan prinsip-prinsip "good governance" dalam pengelolaan pemerintahan menjadi suatu tuntutan utama oleh karena masyarakat mulai kritis dalam memonitor dan mengevaluasi manfaat serta nilai yang diperoleh atas pelayanan dari instansi pemerintah. Disisi lain pengukuran keberhasilan maupun kegagalan instansi pemerintah dalam menjalankan tugas pokok dan fungsinya sulit dilakukan secara obyekti, disebabkan oleh karena belum diterapkannya sistem pengukuran kinerja yang dapat menginformasikan tingkat keberhasilan secara obyektif dan terukur dari pelaksanaan program program disuatu instansi pemerintah.

Keberhasilan pembangunan nasional, tidak terlepas dari berhasil tidaknya pembangunan daerah, karena pembangunan daerah merupakan bagian integral dari pembangunan nasional sebagi pendukung tercapainya tujuan nasional. Reformasi telah memunculkan banyak perubahan mendasar mengenai perumusan kebijakan serta proses implementasi kegiatan Pemerintah Daerah, khususnya dalam bidang administrasi, serta kebijakan-kebijakan lokal lainnya.

Pelaksanaan desentralisasi di Indonesia melahirkan otonomi daerah dimana penyelenggaraan otonomi daerah membuat setiap daerah mempunyai hak-hak dalam pelaksanaan otonomi daerah tersebut, hak-hak tersebut antara lain mengatur dan mengurus sendiri urusan pemerintahannya, memilih pemimpin daerah, mengelola sumber daya daerah, memungut pajak dan retribusi daerah serta mendapatkan bagi hasil dari pengelolaan sumber daya alam dan sumber pendapatan lain yang sah.

Secara teoritik, Birokrasi Pemerintahan memiliki tiga fungsi utama, yaitu; fungsi pelayanan, fungsi pembangunan dan fungsi pemerintahan umum (LAN, 2007:35): (a) Fungsi pelayanan, berhubungan dengan unit organisasi pemerintahan yang berhubungan langsung dengan masyarakat. Fungsi utamanya, memberikan pelayanan (service) langsung kepada masyarakat; (b) Fungsi pembangunan, berhubungan dengan unit oganisasi pemerintahan yang menjalankan salah satu bidang tugas tertentu disektor pembangunan. Fungsi pokoknya adalah development function / fungsi pembangunan dan adaptive function / fungsi adaptasi; (c) Fungsi pemerintahan umum, berhubungan dengan rangkaian kegiatan organisasi pemerintahan yang menjalankan tugas-tugas pemerintahan umum (regulasi), temasuk di dalamnya menciptakan dan memelihara ketentraman dan ketertiban. Fungsinya lebih dekat pada fungsi pengaturan (regulation function).

Ketiga fungsi birokrasi pemerintahan tersebut, menunjukan bahwa pelayanan publik yang dilaksanakan oleh pemerintahan daerah, cakupannya sangat luas yaitu pelayanan yang menghasilkan public goods/barang publik, seperti jalan, jembatan, pasar dan lainlain, dan pelayanan yang menghasilkan peraturan perundang-undangan atau kebijakan yang harus dipatuhi oleh masyarakat (fungsi regulasi), seperti perizinan, KTP, SIM dan kebutuhan lainnya. 
Kualitas pelayanan pemerintah umumnya kinerjanya masih belum seperti yang diharapkan. Hal ini dapat dilihat antara lain seperti menyangkut prosedur dan mekanisme kerja pelayanan yang berbelit-belit, tidak transparan, kurang informatif, kurang akomodatif, kurang konsisten, terbatasnya fasilitas, sarana dan prasarana pelayanan, sehingga tidak menjamin kepastian (hukum, waktu, dan biaya) serta masih banyak dijumpai praktek pungutan liar serta tindakan-tindakan yang berindikasi penyimpangan dan KKN. Pada hal, berdasarkan hasil penelitian Kheng et al., (2010) yang mengemukakan bahwa service quality akan meningkatkan customer loyalty dan beberapa dimensi dalam service quality memainkan peranan yang signifikan dari pengaruh tersebut.

Buruknya kinerja pelayanan publik ini antara lain dikarenakan belum dilaksanakannya transparansi dan akuntabilitas (prinsip good governance) dalam penyelenggaraan pelayanan publik. Oleh karena itu, pelayanan publik harus dilaksanakan secara transparan dan akuntabel oleh setiap unit pelayanan instansi pemerintah karena kualitas kinerja birokrasi pelayanan publik memiliki implikasi yang luas dalam mencapai kesejahteraan masyarakat. Hal ini juga sesuai dengan ungkapan (Prasojo, 2006) bahwa kualitas dan kinerja birokrasi dalam memberikan pelayanan publik masih jauh dari harapan, karena itulah kekecewaan masyarakat terhadap birokrasi terus terjadi dalam kurun waktu yang lama sejak kita merdeka. Oleh sebab itu menurut (Brandley, 2004) Penelitian administrasi publik memiliki peran khusus yang berorientasi praktis tidak hanya berfungsi sebagai pemandu, diharapkan pengembangan teori juga perlu mempengaruhi tataran praktik dan bahkan keputusan manajer dan pembuat kebijakan.

Mengacu pada fungsi pelayanan, Pemerintah Kabupaten Bolaang Mongondow Utara sebagai salah satu pemerintah daerah di Indonesia wajib untuk memberikan pelayanan publik yang maksimal kepada masyarakatnya. Pelayanan publik yang diberikan Pemerintah Kabupaten Bolaang Mongondow Utara harus secara menyeluruh pada struktur pemerintahan baik di dinas, badan, maupun kantor. Sebagai salah satu bagian Pemerintah Daerah Kabupaten Bolaang Mongondow Utara, Sekretariat daerah berkewajiban untuk memberikan pelayanan publik yang maksimal, apalagi perannya yang mengurusi semua kepentingan pemerintahan, maka pelayanan yang diberikan haruslah secara maksimal.

Namun yang terjadi tidaklah seperti apa yang diharapkan, hal ini berdasarkan data awal yang diperoleh, yang menunjukan banyak pegawai yang tidak disiplin yakni masuk dan keluar kantor yang tidak tepat waktu, mekanisme kerja pelayanan yang berbelit belit, dan berdasarkan observasi awal terhadap pelayanan administrasi dilingkungan sekretariat daerah, membutuhkan waktu dua sampai tiga hari, tidak transparansi. Berdasarkan latar belakang yang memuat harapan dan kenyataan di atas sehingga di lakukan penelitian lebih mendalam mengenai strategi pemerintah daerah dalam meningkatkan pelayanan publik, dengan judul "Strategi Pemerintah Daerah Dalam Meningkatkan Kinerja Pelayanan Publik di lingkungan Sekretariat Daerah Kabupaten Bolaang Mongondow Utara.

Berdasarkan permasalahan diatas, maka yang menjadi tujuan penelitian yakni untuk mengetahui: (a) Strategi Pemerintah Daerah Kabupaten Bolaang Mongondow Utara dalam meningkatkan kinerja pelayanan publik dilingkungan sekretariat daerah; (b) Faktor-faktor apa yang menghambat strategi pemerintah daerah dalam meningkatkan kinerja pelayanan publik dilingkungan sekretariat daerah

Strategi. Menurut Sjafrizal (2009:291) Strategi secara umum diartikan sebagai cara atau alat untuk mencapai tujuan secara lebih baik dan cepat. Sedangkan pengertian strategi itu sendiri berubah dan berkembang dari suatu masa ke masa yang lain, yaitu: (a) Chandler (1962): strategi sebagai alat untuk mencapai tujuan perusahaan (institusi) dalam kaitan 
dengan tujuan jangka panjang,program tindak lanjut serta prioritas alokasi sumber daya; (b) Learned, Christenten Guth (1965): strategi sebagai alat untuk menciptakan keunggulan bersaing; (c) Porter (1985): Strategi sebagai alat yang sangat penting untuk mencapai keunggulan bersaing; (d) Hamel dan Prahalad (1995) mengatakan bahwa strategi merupakan tindakan yang bersifat senantiasa meningkat dan dilakukan berdasarkan sudut pandang tentang apa yang diharapkan pelanggan dimasa depan.

Menurut Makmur (2009:128), strategi adalah suatu tindakan yang berpengaruh dan sangat menentukan keberhasilan terhadap program atau kegiatan, baik yang akan maupun yang telah direncanakan oleh pihak manajemen. Menurut Allison (2013:3), strategi adalah prioritas atau arah keseluruhan yang luas yang diambil oleh organisasi, strategi juga adalah pilihan-pilihan tentang bagaimana cara terbaik untuk mencapai misi organisasi.

Strategi juga tidak terlepas dari yang namanya perumusan strategi, seperti yang dikemukakan oleh Mahmudi (2010:65), tahapan perumusan strategi merupakan tahap penting dalam proses pengendalian manajemen, karena kesalahan dalam merumuskan strategi akan berakibat kesalahan arah organisasi. Sebagai contoh jika suatu kapal ingin berlayar dari Jakarta ke Surabaya, maka kapten kapal harus mengarahkan perjalanan kapalnya ke arah Surabaya. Strategi dan usaha difokuskan untuk mencapai tujuan, yaitu sampai kesurabaya. Jika arah perjalanan kapal salah, strategi yang digunakan tidak tepat, sumber dayanya kurang, tentu kapal itu tidak akan sampai pada tujuan. Sama halnya dengan organisasi, pertama yang harus dilakukan adalah menentukan arah dan tujuan yang hendak dicapai. Setelah arah dan tujuan jelas, maka strategi disusun untuk mencapai arah dan tujuan itu.

Penentuan arah dan tujuan dasar organisasi merupakan bentuk perumusan strategi. Dalam perumusan trategi, organisasi merumuskan misi, visi, tujuan, dan nilai dasar organisasi. Perumusan strategi merupakan kegiatan untuk merancang atau menciptakan masa depan (creating the future). Aktivitas perumusan strategi membutuhkan ketajaman visi dan intuisi. Orang yang memiliki ketajaman visi dan intuisi dapat melihat realitas masa depan yang melampaui realitas masa kini. Kekuatan visi ini sangat besar pengaruhnya dalam menentukan kebesaran organisasi dimasa depan. Osborne dan Gaebler (dalam Mahmudi 2010:62) menyatakan bahwa kekuatan organisasi pemerintah yang digerakkan oleh visi dan misi adalah lebih baik daripada digerakkan oleh aturan-aturan formal

Mahmudi (2010:62), perumusan strategi merupakan tahap pembangunan mental, moral, dan spiritual. Tahap berikutnya berkaitan dengan pembangunan fisik, seperti pemrograman, penganggaran dan implementasi. Tahap pembangunan fisik akan jauh lebih mudah apabila moral, mental, dan spiritual sudah terbangun kokoh.

Selanjutnya, Burhan (dalam Sjafrizal, 2009:190) merinci empat karakteristik dari rencana strategis. Empat karakteristik tersebut adalah (a) menyangkut jangkauan masa depan dari keputusan-keputusan yang dibuat sekarang, (b) merupakan suatu proses yang dimulai dengan menggariskan sarana-sarana, strategis dan kebijakan serta mengembangkan rencana pelaksanaan (Action Plan) untuk mencapai hasil akhir yang diharapkan. (c) merupakan suatu sikap dan cara hidup tertentu karena rencana strategis menuntuk kebiasaan untuk bekerja berdasarkan perkiraan masa depan dan (d) mengaitkan tiga rencana sekaligus yaitu rencana strategis, rencana jangka menegah, dan anggaran jangka pendek. Dengan demikian terlihat bahwa rencana strategis ternyata merupakan sebuah konsep perencanaan untuk jangka menengah yang bersifat strategis dan juga konfrehensif yang dapat diterapkan baik untuk pengembangan kegiatan bisnis maupun 
untuk mendorong proses pembangunan suatu institusi pemerintah atau swasta, baik pada tingkat pusat maupun daerah.

Kinerja. Performance is defined as the record of outcomes produced on a specific job function or activity during a specific time period. Bernardian, John H. \& Joice E. A. Russel, (Sedarmayanti, 2010:260) Kinerja didefinisikan sebagai catatan mengenai out came yang dihasilkan dari suatu aktivitas tertentu, selama kurun waktu tertentu pula.

The Scribner Bantam English Dictionary, (Sedarmayanti, 2010:259) Kinerja (performance) berasal dari akar kata "to perform" yang mempunyai beberapa pengertian: To do or carry out execute. To discharge of fulfil as a vow. To portray, as character in a play. To tender by the voice or musikal instrument. To execute or complete an undertaking. To act a part in a play. To perform musik. To do what is expected of a person or machine. Artinya: Melakukan, menjalankan, melaksanakan. Memenuhi atau menjalankan kewajiban suatu nazar. Menggambarkan suatu karakter dalam suatu permainan. Menggambarkannya dengan suara atau alat musik. Melaksanakan atau menyempurnakan tanggung jawab. Melakukan suatu kegiatan dalam suatu permainan. Memainkan (pertunjukan) musik. Melakukan sesuatu yang diharapkan oleh seseorang atau mesin.

Menurut Amins (2012:47), mengatakan bahwa kinerja adalah sebagai ekspresi potensi berupa perilaku atau cara seseorang atau kelompok orang dalam melaksanakan suatu kegiatan atau tugas sehingga menghasilkan suatu produk yang merupakan wujud dari semua tugas dan tanggungjawab pekerjaan yang diberikan kepadanya. Menurut Uno dan Lamatenggo (2012:63), Kinerja adalah sebagai sebagai perilaku seseorang yang membuahkan hasil kerja tertentu setelah memenuhi sejumlah persyaratan. Pada hasil penelitian Yilmaz dan Tasdan (2009) menemukan bahwa keadilan organisasi terkait dengan perilaku ekstra peran organizational citizenship behavior

Kinerja adalah merupakan gabungan dari tiga faktor penting, yaitu kemampuan dan minat seorang pekerja, kemampuan dan penerimaan atas penjelasan delegasi tugas, serta peran dan tingkat motivasi seorang pekerja. Semakin tinggi ketiga faktor diatas, maka akan semakin besar pula kinerja dari pegawai yang bersangkutan. Hal ini juga sinkron dengan hasil penelitian oleh (Osborn, 2007) Mayer dan Allen; dalam Christie dkk, 2007 pada hasil penelitian pengaruh faktor motivasi terhadap kinerja, menunjukkan bahwa faktor motivasi memiliki pengaruh terhadap kinerja.

Kinerja merupakan kemampuan atau kondisi yang harus diketahui dan diinformasikan kepada pihak-pihak tertentu untuk mengetahui tingkat pencapaian hasil suatu instansi dihubungkan dengan visi yang diemban suatu organisasi serta mengetahui dampak positif dan negatif suatu kebijakan yang diambil. Kinerja adalah gambaran mengenai tingkat pencapaian pelaksana suatu kegiatan/ program/kebijaksanaan dalam mewujudkan sasaran, tujuan, misi, dan visi organisasi yang tertuang dalam perumusan perencanaan strategis (strategic planning) suatu organisasi. Kinerja dapat juga diartikan sebagai prestasi yang dapat dicapai organisasi dalam suatu periode tertentu. Prestasi organisasi merupakan tampilan wajah organisasi dalam menjalankan kegiatannya. Dengan kinerja, organisasi dapat mengetahui sampai peringkat keberapa prestasi keberhasilan atau bahkan mungkin kegagalannya dalam menjalankan amanah yang diterimanya. Kinerja merupakan gambaran mengenai sejauh mana keberhasilan atau kegagalan pelaksanaan tugas pokok dan fungsi instansi. 
Pengukuran kinerja dalam pemerintahan bukanlah suatu aktivitas yang baru. Setiap departemen, satuan kerja, dan unit pelaksana tugas, telah diprogram untuk mengumpulkan informasi berupa laporan berkala (triwulan/semester/tahun) atas pelaksana tugas pokok dan fungsi. Pengukuran kinerja merupakan suatu alat menajemen yang digunakan untuk meningkatkan kualitas pengambilan keputusan dan akuntabilitas. Pengukuran kinerja juga digunakan untuk menilai pencapaian tujuan dan sasaran, James B. Whittaker (Sedarmayanti, 2010:195). Pengukuran kinerja digunakan untuk penilaian atas keberhasilan/kegagalan pelaksanaan kegiatan/program/kebijakan sesuai dengan sasaran dan tujuan yang telah ditetapkan dalam rangka mewujudkan misi dan visi organisasi. Karenanya, sudah merupakan suatu hal yang mendesak untuk menciptakan sistem yang mampu untuk mengukur kinerja dan keberhasilan organisasi. Untuk dapat menjawab pertanyaan tingkat keberhasilan organisasi, maka seluruh aktivitas organisasi tidak semata-mata kepada input dari program organisasi, tetapi ebih ditekankan kepada output, proses, manfaat, dan dampak program organisasi.

Pengukuran kinerja yang dilakukan secara berkesinambungan memberikan umpan balik (feed back), yang merupakan hal penting dalam upaya perbaikan secara terus menerus dan mencapai keberhasilan dimasa yang akan datang. Melalui pengukuran kinerja diharapkan instansi pemerintah dapat mengetahui kinerja dalam suatu periode tertentu. Dengan adanya suatu pengukuran kinerja maka kegiatan dan program instansi pemerintah dapat diukur dan dievaluasi. Pengukuran kinerja setiap instansi dapat diperbandingkan dengan instansi yang sejenis, sehingga penghargaan dan tindakan disiplin dapat dilakukan secara lebih objektif.

Menurut Sudarmanto (2009:11), standar pengukuran kinerja dapat dilakukan dengan mengukur empat hal, yaitu: (1) Pengukuran kinerja dikaitkan dengan analisis pekerjaan, uraian pekerjaan; (2) Pengukuran kinerja dapat dilakukan dengan mengukur sifat/karakter pribadi (traist); (3) Pengukuran kinerja dilakukan dengan mengukur hasil dari pekerjaan yang dicapai; (4) Pengukuran kinerja dilakukan dengan mengukur perilaku atau tindakantindakan dalam mencapai hasil. Menurut Sedarmayanti (2010:195) Pengukuran kinerja penting peranannya sebagai alat manajemen, yaitu sebagai berikut: (1) Memastikan pemahaman para pelaksana akan ukuran yang digunakan untuk pencapaian kinerja; (2) Memastikan tercapainya rencana kinerja yang telah disepakati; (3) Memantau dan mengevaluasi pelaksanaan kinerja dan membandingkannya dengan rencana kerja serta melakukan tindakan untuk memperbaiki kinerja; (4) Memberikan penghargaan dan hukuman yang objektif atas prestasi pelaksana yang telah diukur sesuai dengan sistem pengukuran kinerja yang btelah disepakati; (5) Menjadi alat komunikasi antar bawahan dan pimpinan dalam upaya memperbaiki kinerja organisasi; (6) Mengidentifikasikan apakah kepuasan pelanggan sudah terpenuhi; (7) Membantu memahami proses kegiatan instansi pemerintah; (7) Memastikan bahwa pengambilan keputusan dilakukan secara objektif; (8) Menunjukkan peningkatan yang perlu dilakukan; (9) Mengungkapkan permasalahan yang terjadi. Pengukuran kinerja merupakan hal yang penting dalam manajemen program secara keseluruhan, karena kinerja yang dapat diukur akan mendorong pencapaian kinerja tersebut. Biasanya menggunakan kata-kata "baik”, "efektif”, dan "on-time” untuk menilai secara subjektif atas out put dari suatu program.

Pelayanan Publik. (1) Pelayanan Umum menurut Lembaga Administrasi Negara (dalam Modul 1. 2007:33) diartikan: "Sebagai segala bentuk kegiatan pelayanan umum yang dilaksanakan oleh Instansi Pemerintahan di Pusat dan Daerah, dan di lingkungan 
BUMN/BUMD dalam bentuk barang dan/atau jasa, baik dalam pemenuhan kebutuhan masyarakat maupun dalam rangka pelaksanaan ketentuan Peraturan Perundangundangan”; (2) Departemen Dalam Negeri (dalam Modul 1 LAN. 2007:33) menyebutkan bahwa; "Pelayanan Publik adalah Pelayanan Umum", dan mendefinisikan "Pelayanan Umum adalah suatu proses bantuan kepada orang lain dengan cara-cara tertentu yang memerlukan kepekaan dan hubungan interpersonal tercipta kepuasan dan keberhasilan. Setiap pelayanan menghasilkan produk, baik berupa barang dan jasa”.

Menurut Kurniawan (dalam Pasolong, 2010:199) mengatakan bahwa pelayanan publik adalah pemberian pelayanan (melayani) keperluan orang lain atau masyarakat yang mempunyai kepentingan pada organisasi itu sesuai dengan aturan pokok dan tata cara yang telah ditetapkan.

Menurut Abdussamad (2011:50), pelayanan publik adalah pelayanan yang diberikan pada masyarakat umum yang menjadi warga negara atau yang secara sah menjadi penduduk negara yang bersangkutan. Pengertian ini menegaskan bahwa pada dasarnya pelayanan publik merupakan sebuah proses interaksi antara pihak yang memberikan pelayanan (pemerintah). Secara lebih spesifik lagi, pelayanan publik dapat didefinisikan sebagai segala bentuk kegiatan pelayanan yang dilaksanakan oleh instansi pemerintah dipusat, di daerah dan di lingkungan Badan Usaha Milik Negara/ Daerah dalam bentuk barang dan jas, baik dalam rangka pemenuhan kebutuhan masyarakat maupun dalam rangka pelaksanaan perundang-undangan.

Menurut Surjadi (2012:107-108), untuk meningkatkan kinerja pelayanan publik diperlukan strategi pembaharuan yang mencakup tiga aspek yaitu aspek pembaharuan kelembagaan birokrasi pemerintah, aspek pembaharuan aspek identitas aparatur pemerintah dan aspek pembaharuan proses pelaksanaan kewajiban pemerintah.

Surjadi (2012:55), upaya peningkatan kualitas pelayanan dilakukan dengan mengikuti Siklus Deming yang dinamakan Siklus PDCA dari Dr. W. Edwards Deming yaitu meliputi tahap-tahap sebagai berikut: (1) Tahap Perencanaan (Plan); (2) Tahap Pelaksanaan Bertahap (Do); (3) Tahap Pemeriksan (Check); (4) Tahap Pelaksanaan (Action).

Menurut Surjadi (2012:57), perbaikan kualitas pelayanan harus senantiasa didasarkan pada 3 (tiga) hal: pertama adalah hasil pengukuran indeks kepuasan pelanggan melalui proses penelitian yang cermat, akurat, dan akuntabel serta berkelanjutan. Kedua adalah dari hasil evaluasi kinerja atau hasil pengkajian kinerja yaitu bagaimana kinerja, apa faktor penyebabnya dan bagaimana mengatasinya, dengan memprioritaskan unsur pelayanan yang mendapatkan score rendah dari pengukuran indeks kepuasan pelanggan. Ketiga adalah didasarkan pada perkembangan lingkungan administrasi publik, termasuk didalamnya perkembangan ilmu pengetahuan dan teknologi, sehingga kualitas pelayanan bersifat dinamis, berkembang dari waktu ke waktu. Menurut Anwar (2010) Kemampuan organisasi yang dinamis dihasilkan oleh orang-orang yang mampu, sehingga tanggap membentuk dalam proses perumusan kebijakan dan evaluasi. Dilulio (1991) lebih menekankan bahwa responsif diperlukan dalam agenda pelayanan, prioritas dalam mempersiapkan dan mengembangkan program-program pelayan publik sesuai dengan kebutuhan dan aspirasi masyarakat.

Perlu diperhatikan pula bahwa esensi kepuasan pelanggan pada dasarnya adalah adanya keefektifan dari sistem organisasi yang mampu membantu pelanggan memenuhi kebutuhan secara optimal. Dalam hubungan ini Milind M. Lele dan Jagdish N. Sheth 
(dalam Surjadi, 2012:57) menyatakan bahwa: "memuaskan pelanggan adalah pertahanan yang paling baik untuk melawan pesaing.”

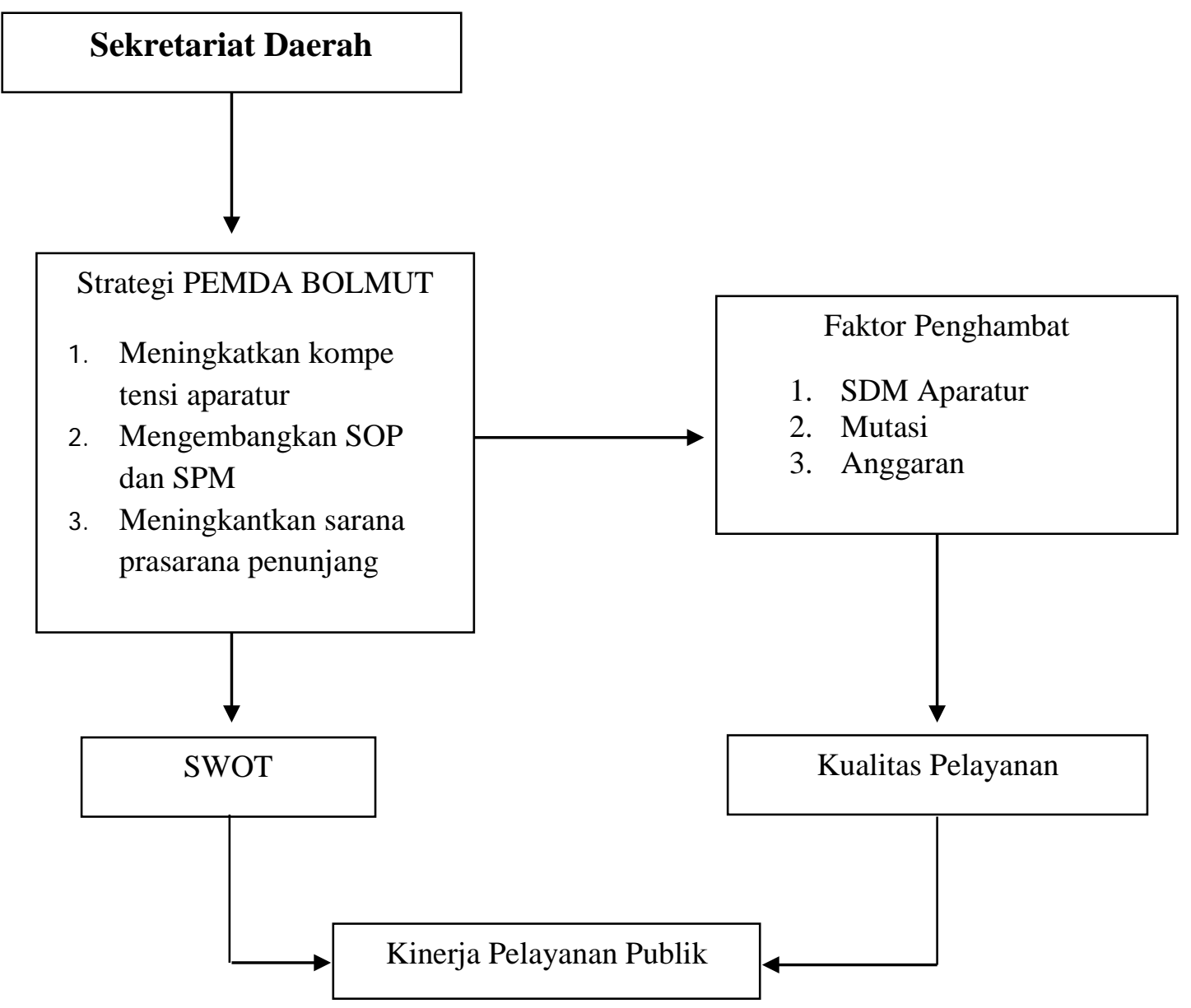

Gambar 1. Kerangka Konsep

\section{METODE}

Dalam penelitian ini menggunakan pendekatan fenomenologis, maksutnya suatu pendekatan dimana peneliti berusaha memahami arti peristiwa dan kaitannya terhadap orang-orang biasa dalam situasi tertentu. Dengan jenis penelitian kualitatif. Berdasarkan rumusan masalah diatas, maka dibatasi permasalahan mengenai kinerja dan strategi pemerintah daerah Kabupaten Bolaang Mongondow Utara dalam meningkatkan kinerja pelayanan publik dilingkungan Sekretariat Daerah. Sehubungan dengan itu, maka fokus penelitian adalah: (1) Strategi berupa meningkatkan kompetensi aparatur, mengembangkan SOP dan SPM, serta meningkantkan sarana prasarana penunjang oleh Pemerintah Daerah Kabupaten Bolaang Mongondow Utara dalam meningkatkan kinerja pelayanan publik dilingkungan Sekretariat Daerah; (2) Faktor-faktor yang menghambat strategi pemerintah daerah dalam meningkatkan kinerja pelayanan publik dilingkungan sekretariat daerah seperti politik, mutasi, dan sumberdaya manusia. 
Sumber Data. Jenis data digunakan penulis dalam penelitian ini terdiri dari: (1) Data primer, yaitu data yang diperoleh langsung dari informan dilokasi penelitian, melalui wawancara dan pengamatan langsung kepada orang-orang yang mempunyai kewenangan dan yang paham dalam hal yang akan diteliti. Yang menjadi informan dalam penelitian ini terdiri dari 9 informan terdiri dari Wakil Bupati 1 orang, Sekda 1 orang, Asisten 2 orang, Kabag 2 orang, Kasubag 1 orang, dan masyarakat 2 orang; (2) Data sekunder, yaitu data yang sudah ada dan didapatkan dilokasi penelitian yang dapat berupa dokumen-dokumen yang mempunyai hubungan dengan permasalahan yang diteliti, literatur-literatur dan lainlain.

Tehnik Analisis Data. Pertama. Reduksi Data ( Pengumpulan data). Merupakan proses seleksi dan penyederhanaan data yang diperoleh dilapangan. Tehnik ini digunakan agar data dapat digunakan sepraktis dan seefisien mungkin, sehingga hanya data yang diperlukan dan dinilai valid yang dijadikan sumber penelitian. Tahap ini berlangsung terus menerus dari tahap awal sampai akhir. (1) Data Display (penyajian data). Merupakan sekumpulan informasi yang tersusun yang memberi kemungkinan adanya penarikan kesimpulan; (2) Conclusion Drawing. Dari awal pengumpulan data peneliti harus sudah mulai mengerti apa arti dari hal-hal yang ditemui. Dari data yang diperoleh di lapangan maka dapat diambil suatu kesimpulan hasil akhir penelitian tersebut; (3) Analisis SWOT. Suatu analisis untuk mengetahui kekuatan, kelemahan, peluang dan tantangan yang dimiliki oleh organisasi. Analisis SWOT ini akan membantu dalam mempersiapkan strategi yang efektif dalam menaggapi isu-isu strategis. Dengan kata lain analisis SWOT membandingkan antara faktor internal (kekuatan dan kelemahan) dengan faktor eksternal (peluang dan tantangan).

Uji keabsahan data meliputi uji credibility, transferability dependability dan confirmability. (1) Credibility atau pengujian kredibilitas data dilakukan dengan perpanjangan pengamatan, peningkatan ketekunan dalam penelitian, triangulasi, diskusi dengan teman sejawat, analsis kasus negative dan memberchek (proses pengecekan data yang diperoleh peneliti kepada pemberi data); (2) Transferability yaitu melakukan transfer data sesuai dengan konteks dan situasi social lain; (3) Dependability dilakukan untuk mengaudit keseluruhan proses penelitian oleh auditor yang independen atau pembimbing; (4) Confirmability, dilakukan mirip dengan dependability sehingga pengujiannya dapat dilakukan secara bersamaan, yaitu menguji hasil penelitian, dikaitkan dengan proses penelitian yang dilakukan.

\section{HASIL DAN PEMBAHASAN}

Strategi Pemerintah Daerah Kabupaten Bolaang Mongondow Utara Dalam Meningkatkan Kinerja Pelayanan Publik Dilingkungan Sekretariat Daerah. Pada hasil penelitian, dengan mengacu pada strategi pemerintah dalam mengembangkan kinerja pelayanan publik yang tertuang dalam Renstra Kabupaten Bolaang Mongondow Utara yaitu: (1) meningkatkan kompetensi aparatur; (2) mengembangkan SOP dan SPM, dan (3) meningkatkan sarana dan prasarana penunjang; (4) Meningkatkan Kompetensi Aparatur. Kompetensi aparatur merupakan pilar utama agar institusi birokrasi dapat melaksanakan tugas-tugas pemerintahan, pembangunan, dan kemasyarakatan. Untuk itulah maka diperlukan adanya langka-langkah dalam upaya pengembangan orientasi perolehan atau kualifikasi yang berhubungan dengan kompetensi-kompetensi yang 
dibutuhkan, agar aparatur birokrasi dapat berperan secara optimal dalam penyelenggaraan pemerintahan, pembangunan dan kemasyarakatan. Dalam hal ini aparatur dituntut untuk memberikan layanan kepada penerima pelayanan publik dengan sepenuh hati, layanan seperti ini tercermin dari kesungguhan aparatur untuk melayani. Seperti yang dikemukakan oleh (Abdussamad, 2014: 66) dengan melalui kompetensi yang dimiliki para para pegawai mampu menyelesaikan suatu tugas/ pekerjaan atau suatu tujuan tertentu denga benar dan efektif sehingga dapat memberikan kontribusi positif bagi suatu organisasi.

Jelas bahwa kompetensi aparatur menjadi sangat bermanfaat dalam menciptakan budaya dan kinerja organisasi yang tinggi, kompetensi diperlukan dalam setiap proses sumber daya manusia. Dari hasil penelitian mengenai Pengaruh OCB terhadap Kinerja Organisasi yang dilakukan oleh Podsakoff dan Mac Kenzie dalam Elovainio (2005: 5-6) bahwa OCB memiliki dampak sebagai berikut: (1) meningkatkan produktivitas rekan kerja, (2) meningkatkan produktivitas pimpinan, (3) menghemat sumber daya yang dimiliki manajemen dan organisasi secara keseluruhan, (4) membantu menghemat energi sumber daya yang langka untuk memelihara fungsi kelompok, (5) dapat menjadi sarana efektif untuk mengkoordinasi kegiatan kelompok kerja, (6) meningkatkan kemampuan organisasi untuk menarik dan mempertahankan karyawan terbaik, (7) meningkatkan stabilitas kinerja organisasi, dan (8) meningkatkan kemampuan organisasi untuk beradaptasi dengan perubahan lingkungan.

Pertama. Mengembangkan SOP dan SPM. Standar Operasional Prosedur (SOP) dan SPM adalah dokumen yang berisi serangkaian instruksi tertulis yang dibakukan mengenai berbagai proses penyelenggaraan administrasi perkantoran yang berisi cara melakukan pekerjaan, waktu pelaksanaan, tempat penyelenggaraan dan aktor yang berperan dalam kegiatan. Sebagai suatu aturan, regulasi, dan kebijakan yang secara terus menerus menjamin perilaku yang benar bagi seluruh pegawai instansi pemerintah maka SOP sangat tepat diterapkan pada aktivitas administrasi perkantoran yang relatif bersifat rutin, berulang serta menghendaki adanya keputusan yang terprogram guna melayani pelanggannya.

Dengan penerapan SOP dan SPM secara konsisten maka administrasi perkantoran memiliki pedoman dalam menyelenggarakan Kebijakan Reformasi Birokrasi yang merupakan suatu kebijakan yang komprehensif dalam peningkatan pelayanan dan kinerja organisasi instansi pemerintah di Indonesia saat ini karena SOP dan SPM selalu dijadikan sebagai acuan dalam melaksanakan tugas bagi pegawai sesuai dengan peraturan yang berlaku dan target kinerja yang telah ditentukan yang selalu dimonitor dan ditinjau ulang setiap periode tertentu untuk mengakomodasi dan mengantisipasi dinamika tugas. Di sisi lain SOP dan SPM juga sekaligus menjadi feedback guna penyesuaian antara kondisi yang dipersyaratkan dalam SOP dengan kondisi riil yang ada guna mencapai kinerja individu dan kinerja organisasi yang optimal. Bahkan dalam jangka panjang, SOP dan SPM dapat dijadikan sebagai langkah perbaikan kinerja pelayanan dan kinerja organisasi berdasarkan konsep manajemen kinerja.

Kedua. Meningkatkan Sarana dan Prasarana Penunjang. Secara umum sarana dan prasarana adalah alat penunjang keberhasilan suatu proses upaya yang dilakukan di dalam pelayanan publik, karena apabila kedua hal ini tidak tersedia maka semua kegiatan yang dilakukan tidak akan dapat mencapai hasil yang diharapkan sesuai dengan rencana. Sarana dan prasarana adalah merupakan seperangkat alat yang digunakan dalam suatu proses kegiatan baik alat tersebut adalah merupakan peralatan pembantu maupun 
peralatan utama, yang keduanya berfungsi untuk mewujudkan tujuan yang hendak dicapai. Setelah diwawancarai beberapa informan, peneliti dapat memilah dan dianalisis dengan menggunakan analis SWOT, peneliti menggunakan Analisis SWOT, karena Analisis SWOT pada dasarnya merupakan identifikasi berbagai faktor dan unsur penentu pembangunan suatu institusi secara sistimatis untuk melakukan evaluasi kondisi lingkup kegiatan bersangkutan dan selanjutnya dapat pula digunakan untuk merumuskan strategi pembangunan institusi yang tepat sesuai dengan kondisi dan potensi yang dimilikinya.

Berdasarkan hasil penelitian dengan mengacu pada tiga hal yang sesuai dengan kerangka pikir, yaitu 1) meningkatkan kompetensi aparatur, 2) mengembangkan SOP dan SPM, dan 3) meningkatkan sarana dan prasarana penunjang, maka peneliti dapat mengelompokkan sesuai dengan analisis SWOT yaitu kekuatan,kelemahan, peluang, dan tantangan yakni sebagai berikut:

Tabel 1. Ringkasan Matriks SWOT

\begin{tabular}{|c|c|}
\hline Faktor Eksternal & Faktor Internal \\
\hline $\begin{array}{l}\text { Peluang } \\
\text { 1. Adanya pelatihan-pelatihan dan Bimtek } \\
\text { 2. Pengembangan kompetensi aparatur } \\
\text { 3. Pengembangan SOP dan SPM } \\
\text { 4. Adanya beasiswa pegawai untuk } \\
\text { melanjutkan studi }\end{array}$ & $\begin{array}{l}\text { Kekuatan } \\
\text { 1. Memiliki komitmen yang kuat untuk } \\
\text { memperbaiki kinerja pelayanan publik } \\
\text { 2. Memiliki Struktur organisasi yang kuat }\end{array}$ \\
\hline $\begin{array}{l}\text { Tantangan } \\
\text { 1. Minimnya sarana prasarana } \\
\text { 2. Lemahnya IT } \\
\text { 3. Adanya pandangan masyarakat yang } \\
\text { kurang baik terhadap pelayanan publik }\end{array}$ & $\begin{array}{l}\text { Kelemahan } \\
\text { 1. Tidak adanya SPM di beberapa bagian } \\
\text { 2. Minimnya anggaran yang di alokasikan }\end{array}$ \\
\hline
\end{tabular}

Berdasarkan penelitian serta wawancara yang dilakukan dan dibuatkan matriks penentu strategi, Sekretariat Daerah Kabupaten Bolaang Mongondow Utara dalam strategi peningkatan kinerja pelayanan publik perlu menggunakan beberapa strategi sebagai berikut:

Tabel 2. Matriks Penentu Strategi

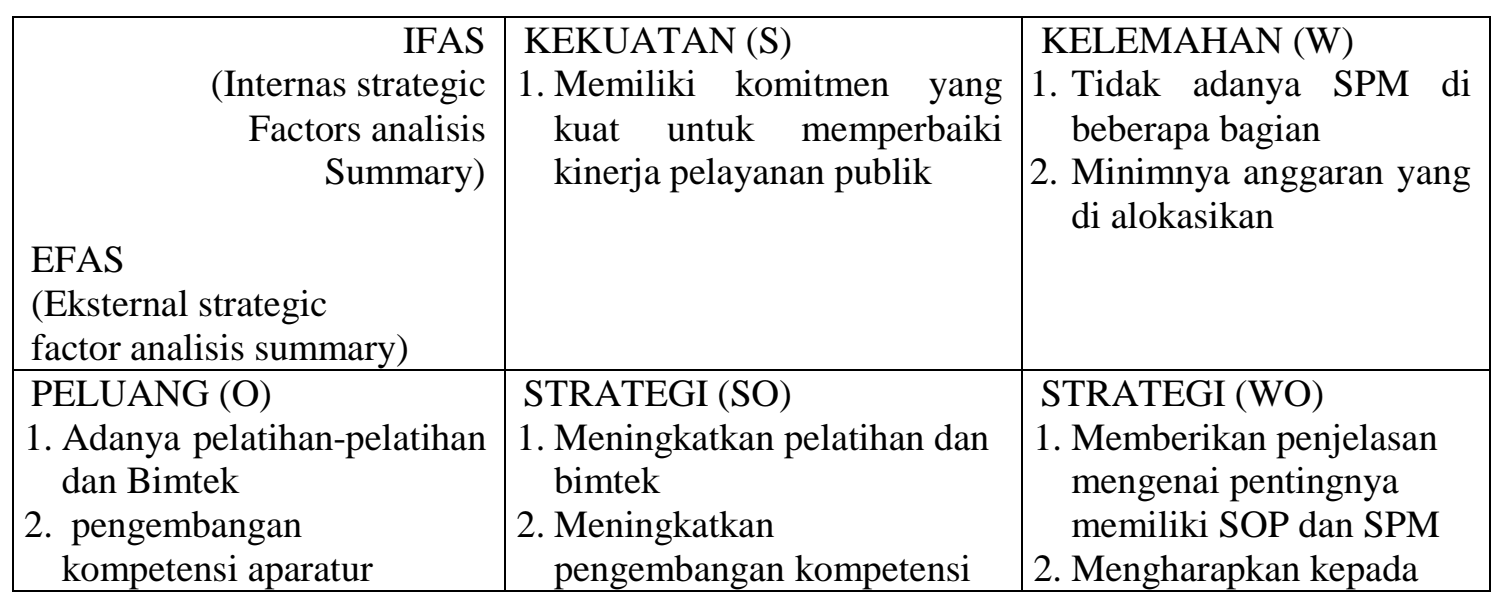




\begin{tabular}{|c|c|c|}
\hline $\begin{array}{l}\text { 3. Pengembangan SOP dan } \\
\text { SPM } \\
\text { 4. Adanya beasiswa pegawai } \\
\text { untuk melanjutkan studi }\end{array}$ & $\begin{array}{l}\text { aparatur. } \\
\text { 3. Meningkatkan SOP dan } \\
\text { SPM serta } \\
\text { mengimplementasikan dalam } \\
\text { kinerja pelayanan publik } \\
\text { 4. Meningkatkan kuantitas } \\
\text { pegawai yang melanjutkan } \\
\text { studi }\end{array}$ & $\begin{array}{l}\text { pemda untuk } \\
\text { mengalokasikan anggaran } \\
\text { yang lebih }\end{array}$ \\
\hline $\begin{array}{l}\text { TANTANGAN (T) } \\
\text { 1. minimnya } \\
\text { prasarana. } \\
\text { 2. Lemahnya IT } \\
\text { 3. Adanya } \\
\text { masyarakat yang kurang } \\
\text { baik terhadap pelayanan } \\
\text { publik }\end{array}$ & $\begin{array}{l}\text { STRATEGI (ST) } \\
\text { 1. Mampu mempertahankan } \\
\text { dan mengimplementasikan } \\
\text { komitmen yang kuat untuk } \\
\text { memperbaiki kinerja } \\
\text { pelayanan publik }\end{array}$ & $\begin{array}{l}\text { STRATEGI (WT) } \\
\text { 1. Mampu meningkatkan } \\
\text { sarana terutama IT } \\
\text { sebagai penunjang } \\
\text { pelayanan publik } \\
\text { 2. Mengoptimalkan kinerja } \\
\text { pelayanan publik agar } \\
\text { menghasilkan opini yang } \\
\text { baik dari masyarakat }\end{array}$ \\
\hline
\end{tabular}

Faktor-Faktor Yang Menghambat Strategi Pemerintah Daerah Dalam Meningkatkan Kinerja Pelayanan Publik Dilingkungan Sekretariat Daerah Kabupaten Bolaang Mongondow Utara. Berdasarkan hasil penelitian, ada beberapa faktor yang menghambat strategi pemerintah daerah dalam meningkatkan kinerja pelayanan publik di lingkungan Sekretariat Daerah Kabupaten Bolaang Mongondow Utara diantaranya adalah: Pertama. Sumber Daya Manusia (SDM). Sumber Daya Manusia dalam suatu organisasi merupakan aset yang mutlak diperlukan, arti penting sumber daya manusia dalam suatu organisasi adalah manusia merupakan elemen yang selalu ada dalam suatu organisasi. Organisasi adalah entitas sosial yang melibatkan sumber daya, konflik pribadi, dan berbagai taktik yang dilakukan oleh individu dan kelompok untuk memperoleh manfaat dan tujuan dengan cara yang berbeda. (Eran, 2000). Mereka membuat tujuan organisasi, melakukan inovasi serta berusaha mencapai tujuan tersbut. Tanpa orang-orang berkualitas tampaknya mustahil bagi organisasi untuk meraih tujuantujuannya. Sehingga perlu adanya manajemen sumber daya manusia yang kuat, Manajemen sumber daya manusia adalah suatu manajemen yang khusus mempelajari hubungan dan peranan manusia dalam organisasi perusahaan. Unsur manajemen sumber daya manusia adalah manusia yang merupakan tenaga kerja pada perusahaan, fokus yang dipelajari manajemen sumber daya manusia ini hanya masalah yang berhubungan dengan tenaga kerja manusia saja.

Hal ini dapat dipahami karena semua kegiatan organisasi tergantung kepada manusia yang mengelola organisasi yang bersangkutan. Oleh sebab itu, sumberdaya manusia tersebut harus dikelola agar dapat berdaya guna dan berhasil guna dalam mencapai tujuan organisasi. Sumber daya manusia di lingkungan Sekretariat Daerah Kabupaten Bolaang Mongondow Utara merupakan salah satu faktor yang menghambat strategi pemerintah daerah dalam meningkatkan kinerja pelayanan publik, karena berdasarkan tingkat pendidikan belum merata dan masih bervariasi pada tingkat pendidikan tertentu.

Kedua. Mutasi. Mutasi personal merupakan suatu pengembangan pegawai yang mengatur perpindahan posisi pegawai dari jabatan atau pekerjaan dan tempat kerja yang dilakukan secara horizontal (rotasi) maupun vertikal (promosi dan demosi). Mutasi 
personal bertujuan untuk memenuhi kebutuhan dan keinginan pegawai dalam pengembangan karier individu sehingga diharapkan pegawai akan mendapatkan semangat kerja yang lebih baik. Semangat kerja adalah keinginan dan kesungguhan seseorang mengerjakan pekerjaannya dengan baik serta berdisiplin untuk mencapai prestasi kerja yang maksimal. Kebutuhan prestasi mempengaruhi minat seseorang yang ingin mencapai jenjang karir yang diinginkan sesuai dengan kerja keras yang dilakukan (Xue, David \& Liang, 2011). Masalah dalam pelaksanaan mutasi personal ini bisa timbul diakibatkan pihak manajemen yang belum tepat dalam mengambil keputusan dan kebijaksanaan serta tindakan yang didasarkan pada kualifikasi, kuantitas, dan minat pegawai yang bersangkutan. Mutasi di lingkungan Sekretariat Daerah Kabupaten Bolaang Mongondow Utara merupakan juga faktor yang menghambat strategi pemerintah daerah dalam meningkatkan kinerja pelayanan publik (tidak terlalu dominan) karena mutasi dilakukan berdasarkan pengalaman kerja (masa kerja) dan karier, namun tidak terlalu berpengaruh karena rata-rata mutasi dilakukan dalam rangka promosi jabatan pegawai yang bersangkutan.

Ketiga. Anggaran. Anggaran merupakan suatu hal yang sangat penting dalam suatu organisasi. Pada organisasi privat atau swasta, anggaran merupakan suatu hal yang sangat dirahasiakan, sedangkan untuk organisasi sektor publik anggaran merupakan suatu hal yang harus diketahui oleh publik untuk dievaluasi, dikritik, dan diberi masukan dalam rangka meningkatkan kinerja instansi pemerintah, sehingga perlu adanya penambahan anggaran pada sekretariat daerah guna menunjang kinerja pelayanan publik. Oleh karena minimnya penganggaran di lingkungan Sekretariat Daerah Kabupaten Bolaang Mongondow Utara bisa menghambat strategi pemerintah daerah dalam meningkatkan kinerja pelayanan publik. Penggunaan anggaran di Sekretariat Daerah Kabupaten Bolaang Mongondow Utara telah disesuaikan dengan Renstra dengan memperhatikan urgen penggunaan dana.

\section{PENUTUP}

Simpulan. berdasarkan pembahasan dan hasil penelitian, maka dapat disimpulkan beberapa hal sebagai berikut: Pertama. Strategi pemerintah daerah dalam meningkatkan kinerja pelayanan publik dilingkungan sekretariat daerah Kabupaten Bolaang Mongondow Utara yaitu: (a) Hasil penelitian yang dilihat dari fokus kompetensi aparatur menunjukan bahwa kompetensi sumber daya manusia yang ada dilingkungan Sekretariat Daerah Kabupaten Bolaang Mongondow Utara masih sangat minim. Hal ini dikarenakan masih sebagian besar pegawai yang belum mendapatkan atau mengikuti pelatihan-pelatihan maupun bimtek yang sessuai dengan tupoksinya; (b) Hasil penelitian yang dilihat dari fokus pengembangan SOP dan SPM menunjukan bahwa yang ada di lingkungan Sekretariat Daerah Kabupaten Bolaang Mongondow Utara belum terlaksana dengan optimal. Hal ini dikarenakan masih adanya beberapa bagian yang ada disekretariat daerah yang belum memiliki SOP dan SPM; (c) Hasil penelitian yang dilihat dari fokus srana prasarana penunjang menunjukan bahwa sarana prasarana di lingkungan Sekretariat Daerah Kabupaten Bolaang Mongondow Utara masih minim dan belum memadai. Hal ini dapat dilihat belum tersedianya peralatan penunjang pelayan; (d) Berdasarkan hasil analisis SWOT, yang menjadi tantangan adalah lemahnya IT dan adanya pandangan masyarakat yang kurang baik terhadap pelayanan publik. Yang menjadi peluang adalah adanya pelatihan-pelatihan dan Bimtek untuk pengembangan kompetensi aparatur serta 
SOP dan SPM, serta adanya beasiswa pegawai untuk melanjutkan studi. Yang menjadi kelemahan adalah tidak adanya SOP dan SPM di beberapa bagian, serta minimnya anggaran. Dan yang menjadi kekuatan adalah pemerintah daerah memiliki komitmen yang kuat untuk memperbaiki kinerja pelayanan publik. Kedua. Faktor-Faktor yang teridentifikasi dapat menghambat strategi pemerintah daerah dalam meningkatkan kinerja pelayanan publik dilingkungan Sekretariat Daerah Kabupaten Bolaang Mongondow Utara adalah Sumber Daya Manusia, Mutasi, dan Anggaran.

Saran. berdasarkan kesimpulan, maka dapat disarankan sebagai berikut. Pertama. Dalam rangka mengoptimalkan strategi pemerintah daerah dalam meningkatkan kinerja pelayanan publik dilingkungan Sekretariat Daerah Kabupaten Bolaang Mongondow Utara maka dipandang perlu untuk melakukan hal diantaranya: (a) Untuk peningkatan kompetensi aparatur, pemerintah daerah harus memberikan kesempatan yang lebih pada semua aparatur maupun pegawai untuk mengikuti pelatiha-pelatihan ataupun bimtek yang berkaitan dengan tugas pokok dan fungsi pegawai, serta memberikan beasiswa lanjut studi kepada sejumlah pegawai; (b) Untuk pengembangan SOP dan SPM, pemerintah daerah perlu mengintenskan pelatihan atau pembinaan pengembangan SOP dan SPM, serta mengsosialisasikan peran penting adanya SOP dan SPM pada sebuah organisasi, dan menegaskan sangat penting adanya keberadaan SOP dan SPM pada organisasi, khususnya pada bagian-bagian yang ada dilingkungan sekretariat daerah; (c) Meningkantkan Sarana Prasarana Penunjang dilingkungan Sekretariat Daerah Kabupaten Bolaang Mongondow Utara, pemerintah perlu memperhatikan dan meningkatkan keberadaan sarana dan prasarana penunjang pelayanan public; (d) Meningkatkan kinerja pelayanan publik dilingkungan sekretariat dareah Kabupaten Bolaang Mongondow Utara agar menghasilkan opini yang baik dari masyarakat. Kedua. Untuk mengatasai faktor-faktor yang dapat menghambat strategi pemerintah daerah dalam meningkatkan kinerja pelayanan publik dilingkungan Sekretariat Daerah Kabupaten Bolaang Mongondow Utara, maka perlu adanya manajemen yang tepat baik pada MSDM, mutasi personal maupun pada anggarannya, jika perlu memberlakukan e-Goverment bagi pemerintahan.

\section{DAFTAR RUJUKAN}

Abdussamad, Zuchri, (2011) Pelayanan Publik Kompotensi dan Komitmen Aparat Dalam Pelayanan Perizinan Terpadu. PT Pustaka Indonesia Press. Jakarta Yogyakarta

(2014) Kompetensi Aparat Dalam Pelayanan Publik, Deepublish,

Amins, Achmad. (2012) Manajemen Kinerja Pemerintah Daerah. LaksBang PRESSindo. yogyakarta

Anwar, Rozan, (2010) "Development of Dynamic Capabilities of Education Service Policy Processes in Jembrana, Bali”. Jurnal Ilmu Administrasi dan Organisasi, Bisnis \& Birokrasi, 17 (3)

Allison, Miichael. (2013) Perencanaan Strategis Bagi Organisasi Nirlaba. Yayasan Pustaka Obor Indonesia. Jakarta

Brandley E Wright, Lepora J. Manigauit, Tamika R. Black (2004) “Quantitative Research Measurement In Public Administration an Assessment" Journal Publications" Administrations \& Society, 35 (6): 747-764 
Christie, anne., Jordan, peter., troth, aslea, Lawrence, Sandra. (2007) "Testing the Links Beetwen Emotional Intelligence and Motivation”, Journal of Management and Organization, 13, (3): 212-224

Dilulio J.D (1991) "Principle Agents: The Cultural Bases of Behavior in a Federal Government Bureaucracy”, Journal of Public Administrations Research and Theory, 4 (3): 277-518

Elovainio, M, et.al., (2005) "Combined Effects Of Uncertainty And Organizational Justice On Employee Healt: Testing The Uncertainty Management Model Of Fairness Judgments Among Finnish Public Sector Employees”. Journal Social Science \& Medicine, 61: 2501-2512

Eran Vigoda, (2000) "Organizational Politic, Job Attitudes, and Work Outcomes: Explorations and Implications for the Public Sector". Journal of Vocational Behavior, 57: 326-347

Kheng, Lo Liang., Mahamad, Osman., Ramayah, T., Musahab, Rahim, (2010) “The Impact of Service Quality on Customer Loyalty: A Study of Bank in Penang, Malaysia” Internasional Journal of Marketing Studies, School of Management University Sain Malaysia (USM), Malaysia, 57-66

Lembaga Administrasi Negara. (2007) Modul 1. Paradigma Kebijakan Pelayanan Publik di Era Otonomi Daerah. Diklat Teknis Pelayanan Publik, Akuntanbilitas, dan Pengelolaan Mutu (Public Makmur. 2009. Teori Manajemen Stratejik Dalam Pemerintahan dan Pembangunan. PT Reflika Aditama. Bandung

Mahmudi. (2010) Manajemen Kinerja Sektor Publik. Sekolah Tinggi Ilmu Manajemen YKPN. Yokyakarta.

Pasolong Harbani. (2010) Kepemimpinan Birokrasi. Alfabeta. Bandung.

Prasojo, Eko. (2006) "Reformasi Birokrasi di Indonesia: Beberapa Catatan Kritis”. Jurnal Ilmu Administrasi dan Organisasi, Bisnis \& Birokrasi , 14 (1): Januari.

Sjafrizal. (2009) Teknik Praktis Penyusunan Perencanaan Pemerintah Daerah. Baduose Media.

Sedarmayanti, (2010) Manejemen Sumber Daya Manusia, Reformasi Birokrasi, dan Menejemen Pegawai Negeri Sipil. PT. Refika Aditama. Bandung.

Sudarmanto. (2009) Kinerja dan Pengembangan Kompetensi SDM Teori Dimensi Pengukuran dan Implementasi Dalam Organisasi. Pustaka Pelajar. Yogyakarta.

Surjadi. (2012) "Pengembangan Kinerja Pelayanan Publik. PT. Refika Aditama. Bandung.

Susartono, (2006) "e-Government di Indonesia”, Spirit Publik. Jurnal Administrasi Negara Fakultas Ilmu Sosial dan Ilmu Politik Universitas Sebelas Maret Surakarta, 2 (1): $2-5$

Uno B Hamzah dan Lamatenggo Nina. (2012) Teori Kinerja dan Pengukurannya. PT Bumi Aksara. Jakarta

Yilmaz, K. \& M. Tasdan, (2009) "Organizational citizenship and organizational justice in Turkish primary schools” Journal of Education Administration, 47 (1)

Xue, F.T., David, Y.K.T \& Liang, CL., (2011) "Factors influencing entrepreneurial intention amnong university students”, International Journal of Social Sciences and Humanity Studies, 3 (1): 487-496 